\title{
Crops and Cropping Systems in Dinajpur Region
}

\author{
B J Shirazy ${ }^{1 *}$, A B M J Islam, M M R Dewan² and S M Shahidullah
}

\begin{abstract}
The development of agricultural planning largely depends on the reliable and comprehensive statistics of the existing cropping patterns, cropping intensity and crop diversity of a particular area, which will provide a guideline to the policy makers, researchers, extensionists and development workers. A study was undertaken over all the upazilas of Dinajpur region during 2016 using pre-tested semi-structured questionnaire with a view to document of the existing cropping patterns, intensity and diversity for the region. The most important cropping pattern Boro-Fallow-T. Aman occupied about $41 \%$ of net cropped area (NCA) of the region with its distribution over all the upazilas. The second largest area, $9 \%$ of NCA, was covered by Wheat-Fallow-T. Aman, which was spread over 18 upazilas. A total of 112 cropping patterns were identified in the whole region. The highest number of cropping patterns was identified 30 in Boda upazila of Panchagarh district while the lowest was 11 in Kaharol upazila of Dinajpur district. The lowest crop diversity index (CDI) was reported 0.708 in Birampur followed by 0.753 in Ghoraghat of Dinajpur. The highest CDI was reported 0.955 in Ranisonkail followed by 0.952 in Baliadangi of Thakurgaon. The range of cropping intensity was recorded 206-249\% whereas the maximum value was found for Khansama of Dinajpur and minimum for Boda of Panchagarh district. As a whole, CDI and cropping intensity for Dinajpur region were calculated 0.924 and $229 \%$ respectively, which indicates that the land use and crop diversification is not quite enough for the national demand.
\end{abstract}

Key words: Cropping patterns, land use, diversity, wheat, rice and cropping intensity

\section{INTRODUCTION}

The agricultural sector plays a vital role in the economy of Bangladesh in terms of its contribution to GDP $15.59 \%$, employment generation, livelihoods and poverty alleviation (BBS, 2015). Bangladesh has very fertile land for crop production though some natural calamities occur frequently. It has 30 agroecological zones (AEZ) in terms of different soil and climatic condition. That is why diversified cropping pattern exists in the country. A cropping pattern is defined as yearly sequences of crop production in a piece of land grown in the course of a year (Alam, 1994). The cropping patterns of a region are closely influenced by the geo-climatic, socio-economic, historical and political factors (Hossain, 1996). It is also dependent on physical, historical, social, institutional and economic factors as well as government policies (Agrawal and Kassam, 1976). The cropping pattern and the changes therein depend on a large number of factors like climate, soil type, rainfall, agricultural technology, availability of irrigation facilities and other inputs, marketing and transport facilities and growth of agro-industries (Neena, 1998; Gadge, 2003; Rashid et al., 2005). Ricebased cropping pattern shows dominancy in Bangladesh for the highest demand of rice as staple food and suitable condition for rice production (Shirazy et al., 2016). Dinajpur agricultural region comprises three districts viz Dinajpur, Thakurgaon and Panchagarh. A unique character of this region is its extralong winter season, which favors the successful production of numerous winter crops. Soils are mainly non-calcareous light-textured with less fertility. Occasional flash floods are prevailing in some specific locations. Short duration of rainy season and less availability of irrigation water are the limiting factors for production of diversified crops (FAO, 1988).

${ }^{1}$ Rice Farming Systems Division, BRRI, Gazipur; ${ }^{2}$ BRRI RS Kushtia; *Corresponding author's E-mail: bir.samrat@yahoo.com 
Cultivable land is declining day by day so that escalating cropping intensity with more production and bringing the barren land under cultivation is the pre-requisite for sustainable food security of Bangladesh. Although the country is nearly self-sufficient in rice production, other foods such as vegetables, pulses, oil crops etc. are still deficit to a large extent. Even rice food security has not been achieved at the household level in many poor and extreme poor farm families (Shopan et al., 2012). Therefore, crop diversification will increase cropping intensity, raising the productivity of land and labor, generate income and employment which in turn will eliminate food and nutritional insecurity and poverty of farming community of the Dinajpur region. From the above circumstances, the present study was undertaken for satisfying the following objectives to:

- Find out the existing cropping patterns scenario for Dinajpur region

- Understand the current land use pattern at upazila and regional level

- Visualize the cropping intensity and diversity at local and regional level.

\section{METHODOLOGY}

Twenty-three upazilas of Dinajpur, Thakurgaon and Panchagarh districts under Dinajpur agricultural region were the locale of this study. Data were collected using double stage procedure. At initial stage, data were collected through pre-tested semi-structured questionnaire from 23 preassigned Sub-Assistant Agriculture Officers (SAAO) of each upazila during July 2016 at upazila level. SAAOs were purposively preselected by Agriculture Extension Officers (AEO), Additional Agriculture Officer (AAO) and Upazila Agriculture Officer (UAO) or altogether. Prior to data collection, the pretested questionnaire was explained along with proper guidelines to the AEOs or UAOs or both and handed over to them at each Deputy Director's office of Department of Agricultural
Extension (DAE) during monthly meeting for the sake of accurate data collection. The filled questionnaires were collected by the scientists of RFS Division, checked and analyzed to find the inconsistencies of the supplied data before validation workshop. All the inconsistencies among the information were documented. The collected data along with documented inconsistencies were discussed in district level workshop for necessary correction and validation. The second stage of data collection was daylong data validation workshop at district level. The workshop dates were 1 September for Dinajpur; 4 October for Panchagarh; and 6 October 2016 for Thakurgaon. Four fieldworkers i.e. one SAPPO and three SAAOs experienced and engaged in crop-based data documentation, all officers from all upazilas viz UAOs, AEOs, AAEOs, DD (DAE), DD (Horticulture), DD of Seed Certification Agency, DTO and ADDs, one representative from Agricultural Training Institute (ATI) and scientists of BRRI regional station, Rangpur participated in the data validation workshop. The number of participants of validation workshop ranged from 43 to 98 in each district. All the participants were divided into three to four groups for data validation. Each group was facilitated by two RFSD scientists to finalize and validate the data and authenticated data were captured. Crop diversity index was calculated by using the following equation described by Kshirsagar et al. (1997).

$$
C D I_{i}=1-\sum_{j=o}^{n}\left(\frac{a_{i j}}{A_{i}}\right)^{2}
$$

Where, $\mathrm{CDI}_{\mathrm{i}}=$ Crop Diversity Index $\mathrm{a}_{\mathrm{ij}}=$ Area planted to the $\mathrm{j}^{\text {th }}$ crop in the $\mathrm{i}^{\text {th }}$ location

$A_{i}=$ Total area planted under all crops

The index is zero for a land area growing only one crop. It approaches unity as the level of diversity increases. Compilation and processing of collected data were done using Micro Soft Excel programme. Descriptive statistics were used to facilitate the presentation of the findings. 


\section{RESULTS AND DISCUSSION}

\section{Land use}

Net cropped area of Dinajpur agricultural region is 527,440 (Table 1 ). The cropping intensity (CI) of the region is $229 \%$ which is much higher than the national average. Crops occupied the particular land for round the year were considered under annual crops. The major annual crops reported in the region were sugarcane, banana, papaya, betel leaf, ginger and turmeric. The annual crops area in different upazilas ranged from 30 to 1,700 ha. The annual crops area accounted for only $1.79 \%$ of the net cropped area (NCA) in the region. At a glance, the region possesses $1.25 \%$ single cropped area (SCA), $64.66 \%$ double cropped area (DCA), $31.68 \%$ triple cropped area (TCA) and a very little amount $(0.04 \%)$ of quadruple cropped area (QCA) which exists only in Bochaganj and Hakimpur upazila. The DCA had the major share of NCA in all the upazilas of Dinajpur, Thakurgaon and Panchagharh district except Khansama of Dinajpur district, Baliadangi and Haripur of Thakurgaon district where triple cropped area is the dominant one (Table 1). The area which could not be defined under SCA, DCA, TCA or QCA was considered as others whose coverage is less than $1 \%$ of the NCA.

\section{Cropping patterns of Dinajpur}

In total 112 cropping patterns were observed in Dinajpur region of which only four cropping patterns with exclusive rice crop covers over $41 \%$ of the NCA. There were 32 cropping patterns with exclusive non-rice crop covering about $5 \%$ of the NCA. Rest of the NCA i.e. around $54 \%$ areas is covered by 74 rice non-rice cropping patterns (Appendix 1).

\section{Rice and non-rice crops at a glance}

In Dinajpur region, $41.40 \%$ of NCA was covered by exclusively rice-based cropping patterns (Table 2). The highest area coverage (40.92\%) was recorded by double rice, Boro-Fallow-T. Aman cropping pattern which was found in all the upazilas. Altogether, single and triple rice based pattern occupied less than $1 \%$ of NCA. Triple rice based pattern Boro-Aus-T. Aman was reported in seven upazilas while single rice pattern was reported only in five upazilas.

In the current investigation, 32 cropping patterns were identified that were free from rice. Among these 32 patterns first 18 have been arranged in descending order in Table 3 . The rest 14 patterns with negligible area coverage (Table 7) are arranged with other patterns of different categories. Aggregate of the 32 patterns have had approximately $5 \%$ of NCA. In critical comparison it is clear that exclusive rice area is about nine folds of exclusive non-rice area. Among these 32 patterns, year-round vegetable production system has the highest area coverage that practiced on or around the homestead area. Appropriate cropping patterns may facilitate maximum possible land use as well as efficient use of other scarce resources in a sustainable manner. Diversified cropping pattern may be an option for the farmers as a coping strategy against risks (Mandal and Bezbaruah, 2013). Typology of different cropping systems is the base for the managers of these systems to intensify production (Shriar, 2000).

\section{Non-rice cereal crops}

Thirty-five cropping patterns are holding different non-rice cereal crops (Table 4). Among them wheat, with the largest area, is leading 14 patterns cultivated on 111,220 hectares that is equivalent to $21.08 \%$ of NCA. Maize holds the second position in non-rice cereal crop cultivation in Dinajpur region. There are 23 cropping patterns for maize, which in-together occupy $19.28 \%$ of NCA. In the documentation of non-rice cereal cropping systems wheat reported widest spreading e.g. Wheat-Jute-T. Aman is distributed over 20 upazilas out of 23. Overall, the aggregate area of the non-rice ricecereal cropping system stands for $37.23 \%$ of the NCA in Dinajpur region. In Bangladesh there is a vast market of maize seeds for feed industries. Loam and sandy-loam soil of the comparative dry area is very suitable for maize cultivation. Wheat cultivation with its better yield in this region is specially favoured by long winter season that is normally unavailable in southern parts of the country. Light textured soil with 
Table 1. Land use of different upazilas in Dinajpur region (area in hectare), 2014-15.

\begin{tabular}{|c|c|c|c|c|c|c|c|c|c|c|}
\hline & Upazila & $\begin{array}{l}\text { Area of } \\
\text { upazila }\end{array}$ & $\begin{array}{r}\text { Annual } \\
\text { crop }\end{array}$ & SCA & DCA & TCA & QCA & Other & $\mathrm{NCA}$ & C.I. (\%) \\
\hline 01 & Birampur & 21283 & 50 & 200 & 14450 & 2760 & 0 & 140 & 17600 & 214 \\
\hline 02 & Birganj & 41312 & 300 & 0 & 17510 & 13110 & 0 & 130 & 31050 & 241 \\
\hline 03 & Biral & 35358 & 120 & 150 & 15700 & 14060 & 0 & 190 & 30220 & 246 \\
\hline 04 & Bochaganj & 22489 & 530 & 40 & 11730 & 7450 & 200 & 180 & 20130 & 236 \\
\hline 05 & Chirirbandar & 31285 & 360 & 0 & 18370 & 4910 & 0 & 120 & 23760 & 219 \\
\hline 07 & Phulbari & 22851 & 50 & 20 & 13800 & 4730 & 0 & 150 & 18750 & 225 \\
\hline 08 & Ghoraghat & 14874 & 65 & 50 & 10245 & 1490 & 0 & 110 & 11960 & 212 \\
\hline 09 & Hakimpur & 9993 & 30 & 0 & 6110 & 2015 & 10 & 115 & 8280 & 225 \\
\hline 10 & Kaharol & 20555 & 600 & 0 & 13400 & 3800 & 0 & 100 & 17900 & 218 \\
\hline 11 & Khansama & 17972 & 320 & 150 & 6710 & 7915 & 0 & 125 & 15220 & 249 \\
\hline 15 & Boda & 34998 & 340 & 250 & 20750 & 1980 & 0 & 120 & 23440 & 206 \\
\hline 16 & Debiganj & 30905 & 690 & 1450 & 14690 & 7210 & 0 & 150 & 24190 & 221 \\
\hline 17 & Panchagarh & 33844 & 640 & 1950 & 18360 & 3420 & 0 & 170 & 24540 & 203 \\
\hline 18 & Tetulia & 18909 & 240 & 450 & 6720 & 6180 & 0 & 150 & 13740 & 240 \\
\hline 19 & Baliadangi & 28425 & 80 & 1100 & 11120 & 11250 & 0 & 130 & 23680 & 243 \\
\hline 20 & Haripur & 20115 & 160 & 240 & 8470 & 8680 & 0 & 110 & 17660 & 247 \\
\hline 21 & Pirganj & 35414 & 550 & 300 & 19470 & 9190 & 0 & 140 & 29650 & 228 \\
\hline 22 & Ranisonkail & 28748 & 300 & 30 & 12270 & 11450 & 0 & 150 & 24200 & 246 \\
\hline 23 & Thakurgaon & 68375 & 1700 & 40 & 29030 & 22320 & 0 & 110 & 53200 & 239 \\
\hline
\end{tabular}

Table 2. Cropping patterns with exclusive rice in Dinajpur region, 2014-15.

\begin{tabular}{llrrr}
\hline & Cropping pattern & Area (ha) & \% of NCA & Frequency (no. of upazila) \\
\hline 01 & Boro-Fallow-T. Aman & 215850 & 40.92 & 23 \\
02 & Boro-Aus-T. Aman & 1575 & 0.30 & 7 \\
03 & Boro-Fallow-Fallow & 650 & 0.12 & 3 \\
04 & Fallow-Fallow-T. Aman & 300 & 0.06 & 2 \\
\hline & Total & 218375 & 41.40 & \\
\hline
\end{tabular}

low water-holding capacity as well as less availability of irrigation water is driving forces that discourage the farmers for modern Boro cultivation. During the harvesting period of wheat, the crop is privileged by clear sun-shine and low humidity. All these are the factors this area is dominated by wheat-based cropping systems (FAO, 1988).

\section{Pulses and oil-seed crops}

There were 34 cropping patterns of pulse and oil-seed crops where eight patterns had been led by mustard alone (Table 5). Mustard is the most important among all the oil-seed crops in the region. The total share of pulses and oil-seed crops is $8.16 \%$ of NCA whereas mustard absolutely occupies about 5\%. Along with its widest coverage Mustard-Boro-T. Aman pattern was reported from 21 upazilas out of 23. On the other hand, the total pulse crops occupied only around $1 \%$ of NCA where mungbean was dominant.

\section{Vegetables and spices crops}

Fifty-two cropping patterns have been arranged in descending order according to area coverage in Table 6. Potato and other vegetables of Rabi, Kharif-I and Kharif-II; spices viz chilli, onion, 
Table 3. Cropping patterns with exclusive non-rice in Dinajpur region, 2014-15.

\begin{tabular}{|c|c|c|c|c|}
\hline & Cropping pattern & Area (ha) & $\%$ of NCA & Frequency (no. of upazila) \\
\hline 01 & Vegetab-Vegetab-Vegetab & 5070 & 0.96 & 18 \\
\hline 02 & Wheat-Fallow-Fallow & 3250 & 0.62 & 3 \\
\hline 03 & Wheat-Maize-Fallow & 3050 & 0.58 & 3 \\
\hline 04 & Wheat-Maize-Vegetab & 2000 & 0.38 & 2 \\
\hline 05 & Maize-Vegetab-Fallow & 1700 & 0.32 & 3 \\
\hline 06 & Potato-Maize-Fallow & 1600 & 0.30 & 1 \\
\hline 07 & Wheat-Vegetab-Vegetab & 1400 & 0.27 & 2 \\
\hline 08 & Groundnut-Fallow-Fallow & 1330 & 0.25 & 2 \\
\hline 09 & Onion-Vegtab-Vegetab & 850 & 0.16 & 8 \\
\hline 10 & Garlic-Vegetab-Vegetab & 710 & 0.13 & 7 \\
\hline 11 & Vegetab-Jute-Fallow & 520 & 0.10 & 2 \\
\hline 12 & Vegetab-Fallow-Fallow & 470 & 0.09 & 2 \\
\hline 13 & Vegetab-Fallow-Blackgram & 405 & 0.08 & 5 \\
\hline 14 & Potato-Maize-Vegetab & 350 & 0.07 & 1 \\
\hline 15 & Vegetab-Vegetab-Fallow & 310 & 0.06 & 3 \\
\hline 16 & Chilli-Fallow-Fallow & 240 & 0.05 & 3 \\
\hline 17 & Potato-Jute-Fallow & 200 & 0.04 & 1 \\
\hline 18 & Chilli-Vegetab-Fallow & 160 & 0.03 & 3 \\
\hline \multirow[t]{2}{*}{$19-32$} & Other 14 patterns (in table 7 ) & 980 & 0.19 & \\
\hline & Total & 24595 & 4.66 & \\
\hline
\end{tabular}

Table 4. Non-rice cereal crops under different cropping systems in Dinajpur region, 2014-15.

\begin{tabular}{|c|c|c|c|c|}
\hline & Cropping pattern & Area (ha) & $\%$ of NCA & Frequency (no. of upazila) \\
\hline 01 & Wheat-Fallow-T. Aman & 46660 & 8.84 & 18 \\
\hline 02 & Maize-Fallow-T. Aman & 45980 & 8.71 & 18 \\
\hline 03 & Potato-Maize-T. Aman & 26330 & 4.99 & 18 \\
\hline 04 & Wheat-Jute-T. Aman & 23960 & 4.54 & 20 \\
\hline 05 & Wheat-Maize-T. Aman & 11520 & 2.18 & 7 \\
\hline 06 & Wheat-Aus-T. Aman & 9990 & 1.89 & 13 \\
\hline 07 & Wheat-Mungbean-T. Aman & 6280 & 1.19 & 14 \\
\hline 08 & Mustard-Maize-T. Aman & 3590 & 0.68 & 10 \\
\hline 09 & Wheat-Fallow-Fallow & 3250 & 0.62 & 3 \\
\hline 10 & Wheat-Maize-Fallow & 3050 & 0.58 & 3 \\
\hline 11 & Wheat-Vegetab-T. Aman & 2920 & 0.55 & 8 \\
\hline 12 & Wheat-Maize-Vegetab & 2000 & 0.38 & 2 \\
\hline 13 & Maize-Maize-T. Aman & 1700 & 0.32 & 1 \\
\hline 14 & Maize-Vegetab-Fallow & 1700 & 0.32 & 3 \\
\hline 15 & Potato-Maize-Fallow & 1600 & 0.30 & 1 \\
\hline 16 & Wheat-Vegetab-Vegetab & 1400 & 0.27 & 2 \\
\hline 17 & Maize-Boro-T. Aman & 1200 & 0.23 & 1 \\
\hline 18 & Vegetab-Maize-T. Aman & 1020 & 0.19 & 6 \\
\hline 19 & Maize-Jute-T. Aman & 440 & 0.08 & 2 \\
\hline 20 & Potato-Maize-Vegetab & 350 & 0.07 & 1 \\
\hline 21 & Maize-Aus-Fallow & 300 & 0.06 & 2 \\
\hline 22 & Maize-Vegetab-T. Aman & 300 & 0.06 & 2 \\
\hline 23 & Maize-Aus-T. Aman & 250 & 0.05 & 1 \\
\hline 24 & Millet(kaon)-Fallow-T. Aman & 10 & 0.00 & 1 \\
\hline $25-35$ & Other 11 patterns (in table 7 ) & 665 & 0.13 & - \\
\hline & Total non-rice cereal crops & 196465 & 37.23 & \\
\hline
\end{tabular}


Table 5. Cropping patterns with pulses and oil-seed crops in Dinajpur region, 2014-15.

\begin{tabular}{llcc}
\hline Cropping pattern & Area (ha) & \% of NCA & Frequency (no. of upazila) \\
\hline 01 Mustard-Boro-T. Aman & 18720 & 3.55 & 21 \\
02 Wheat-Mungbean-T. Aman & 6280 & 1.19 & 14 \\
03 Groundnut-Fallow-T. Aman & 3700 & 0.70 & 5 \\
04 Mustard-Maize-T. Aman & 3590 & 0.68 & 10 \\
05 Potato-Groundnut-T. Aman & 2700 & 0.51 & 3 \\
06 Sesame-Fallow-T. Aman & 2010 & 0.38 & 2 \\
07 Mustard-Boro-Fallow & 1490 & 0.28 & 3 \\
08 Groundnut-Fallow-Fallow & 1330 & 0.25 & 2 \\
09 Fallow-Sesame-T. Aman & 700 & 0.13 & 1 \\
10 Vegetab-Fallow-Blackgram & 405 & 0.08 & 5 \\
11 Mustard-Jute-T. Aman & 380 & 0.07 & 3 \\
12 Mustard-Fallow-T. Aman & 360 & 0.07 & 2 \\
13 Groundnut-Jute-T. Aman & 300 & 0.06 & 1 \\
14 Vegetab-Groundnut-T. Aman & 300 & 0.06 & 2 \\
15 Mustard-Aus-T. Aman & 160 & 0.03 & - \\
$16-34$ Other 19 patterns (in Table 7) & 630 & 0.12 & \\
\hline Total pulses and oil-seed crops & 43055 & 8.16 & \\
\hline
\end{tabular}

garlic are included in this list. Here, potato based pattern is the most contributing cropping pattern that covers more than $12 \%$ of NCA. In addition, Potato-Boro-T. Aman and PotatoMaize- T. Aman pattern occupies the largest area than the other patterns. In total the area for vegetables and spices covered one-fifth of NCA in the Dinajpur region

\section{Sporadic and distinct cropping patterns}

There are some cropping patterns, which are extremely location-specific, however, with a large area coverage. These are Maize-Maize-T. Aman, Maize-Boro-T. Aman (Table 4) and PotatoMaize-Fallow (Table 6). Maize-Maize-T. Amanis grown on 1,700 hectares of land in Birol upazila of Dinajpur district. The Maize-Boro-T. Amanis limited to Dinajpur sadar upazila covering 1,200 hectares of area. Potato-Maize-Fallow is limited to only Ranisonkail upazila of Thakurgaon district with area coverage of 1,600 hectares.

\section{Rare cropping patterns}

In the present investigation, 40 cropping patterns have been identified as rare cropping patterns with negligible area coverage with seldom existence (Table 7). These are location specific system and are limited in one or two or in some cases three upazilas of the region. Total area coverage of the 40 patterns is far below than $1 \%$ of NCA. Among them, top three patterns viz Chilli-Vegetab-T. Aman (150 ha), Maize-JuteFallow (150 ha) and Vegetab-Jute-T. Aman (150 ha) were recorded separately in one upazila of the region. The smallest area was recorded for Maize-Sesame-T. Aman cropping patterns whose coverage was five hectares for each (Table 7).

\section{Most dominant cropping pattern}

Boro-Fallow-T. Aman was the most dominant cropping pattern in Dinajpur region. It covers $40.91 \%$ of NCA in the region and is available in all upazilas of the region (Table 8). The highest area under this cropping was recorded 20,800 hectares in Parbatipur upazila which represents $9.64 \%$ of the total Boro-Fallow-T. Aman area of the region. In consideration of individual upazila Birampur has allocated the highest area and it is over $80 \%$ of its NCA for this pattern alone. Atwari upazila had the lowest area coverage for this pattern, which was $14.11 \%$ of NCA and $1.07 \%$ of the pattern in that region. In the countrywide compilation of data it was observed that Boro-F- T. Aman was the most dominant 
Table 6. Cropping patterns with vegetables and spices crops in Dinajpur region, 2014-15.

\begin{tabular}{|c|c|c|c|c|}
\hline & Cropping pattern & Area (ha) & $\%$ of NCA & Frequency (no. of upazila) \\
\hline 01 & Potato-Boro-T. Aman & 26590 & 5.04 & 16 \\
\hline 02 & Potato-Maize-T. Aman & 26330 & 4.99 & 18 \\
\hline 03 & Chilli-Fallow-T. Aman & 7560 & 1.43 & 10 \\
\hline 04 & Vegetab-Vegetab-Vegetab & 5070 & 0.96 & 18 \\
\hline 05 & Vegetab-Fallow-T. Aman & 4460 & 0.85 & 8 \\
\hline 06 & Potato-Jute-T. Aman & 3515 & 0.67 & 7 \\
\hline 07 & Wheat-Vegetab-T. Aman & 2920 & 0.55 & 8 \\
\hline 08 & Potato-Groundnut-T. Aman & 2700 & 0.51 & 3 \\
\hline 09 & Vegetab-Vegetab-T. Aman & 2650 & 0.50 & 8 \\
\hline 10 & Potato-Vegetab-T. Aman & 2460 & 0.47 & 8 \\
\hline 11 & Potato-Aus-T. Aman & 2020 & 0.38 & 4 \\
\hline 12 & Wheat-Maize-Vegetab & 2000 & 0.38 & 2 \\
\hline 13 & Maize-Vegetab-Fallow & 1700 & 0.32 & 3 \\
\hline 14 & Potato-Maize-Fallow & 1600 & 0.30 & 1 \\
\hline 15 & Potato-Fallow-T. Aman & 1440 & 0.27 & 4 \\
\hline 16 & Wheat-Vegetab-Vegetab & 1400 & 0.27 & 2 \\
\hline 17 & Vegetab-Maize-T. Aman & 1020 & 0.19 & 6 \\
\hline 18 & Garlic-Jute-T. Aman & 980 & 0.19 & 8 \\
\hline 19 & Onion-Vegtab-Vegetab & 850 & 0.16 & 8 \\
\hline 20 & Onion-Jute-T. Aman & 740 & 0.14 & 6 \\
\hline 21 & Garlic-Vegetab-Vegetab & 710 & 0.13 & 7 \\
\hline 22 & Chilli-Jute-T. Aman & 670 & 0.13 & 5 \\
\hline 23 & Garlic-Fallow-T. Aman & 570 & 0.11 & 6 \\
\hline 24 & Onion-Fallow-T. Aman & 560 & 0.11 & 5 \\
\hline 25 & Vegetab-Jute-Fallow & 520 & 0.10 & 2 \\
\hline 26 & Potato-Boro-Fallow & 500 & 0.09 & 1 \\
\hline 27 & Potato-Onion-T. Aman & 500 & 0.09 & 1 \\
\hline 28 & Vegetab-Fallow-Fallow & 470 & 0.09 & 2 \\
\hline 29 & Vegetab-Fallow-Blackgram & 405 & 0.08 & 5 \\
\hline 30 & Garlic-Aus-T. Aman & 350 & 0.07 & 3 \\
\hline 31 & Potato-Maize-Vegetab & 350 & 0.07 & 1 \\
\hline 32 & Onion-Aus-T. Aman & 300 & 0.06 & 2 \\
\hline 33 & Chilli-Fallow-Fallow & 240 & 0.05 & 3 \\
\hline 34 & Potato-Jute-Fallow & 200 & 0.04 & 1 \\
\hline 35 & Chilli-Vegetab-Fallow & 160 & 0.03 & 3 \\
\hline $36-52$ & Other 17 patterns (in Table 7) & 1030 & 0.20 & \\
\hline & Total veg and spices crops & 105540 & 20.01 & \\
\hline
\end{tabular}

cropping pattern in Bangladesh covering 2.31 million ha ( $27 \%$ of NCA in the country) with its distribution in 426 upazilas of 63 districts (Nasim et al., 2017).

\section{Second dominant cropping pattern}

The second dominant cropping pattern in Dinajpur region is Wheat-Fallow-T. Aman. It belongs to $8.84 \%$ of NCA of the region and spread out over 18 upazilas (Table 9). Thakurgaon sadar upazila hold the highest area $(7,500 \mathrm{ha})$ under this cropping pattern with $16 \%$ share of the region alone. Regarding NCA percentage Pirganj upazila occupied over 22\% of NCA, which was the highest of that region. The four upazila namely Debiganj, Nawabganj, Parbatipur and Hakimpur shared very little area as less than $1 \%$ of NCA. 
Table 7. Rare cropping patterns covering non-significant area in Dinajpur region, 2014-15.

\begin{tabular}{|c|c|c|c|c|c|}
\hline & Cropping pattern & Area (ha) & $\%$ of NCA & Freq. & Upazila \\
\hline 01 & Chilli-Vegetab-T. Aman & 150 & 0.03 & 1 & Dinajpur \\
\hline 02 & Maize-Jute-Fallow & 150 & 0.03 & 1 & Tetulia \\
\hline 03 & Vegetab-Jute-T. Aman & 150 & 0.03 & 1 & Boda \\
\hline 04 & W.Melon-Fallow-Fallow & 140 & 0.03 & 3 & Bochaganj+Boda+Debiganj \\
\hline 05 & Onion-Maize-T. Aman & 130 & 0.02 & 2 & Debiganj+Baliadangi \\
\hline 06 & S.Potato-Vegetab-Fallow & 120 & 0.02 & 2 & Parbatipur+Chirirbandar \\
\hline 07 & S.Potato-Fallow-T. Aman & 110 & 0.02 & 3 & Pirganj+Debiganj+Ghoraghat \\
\hline 08 & Maize-Fallow-Fallow & 100 & 0.02 & 1 & Debiganj \\
\hline 09 & Onion-Jute-Fallow & 90 & 0.02 & 1 & Khansama \\
\hline 10 & Fallow-Fallow-Blackgram & 80 & 0.02 & 3 & Phulbari+Tetulia+Haripur \\
\hline 11 & Wheat-Sesame-T. Aman & 80 & 0.02 & 3 & Atwari+Ranisonkail+Thakurgaon \\
\hline 12 & Chilli-Aus-T. Aman & 70 & 0.01 & 1 & Pirganj \\
\hline 13 & Maize-Aus-Blackgram & 70 & 0.01 & 1 & Chirirbandar \\
\hline 14 & Wheat-Jute-Fallow & 60 & 0.01 & 1 & Khansama \\
\hline 15 & Coriander-Fallow-Fallow & 50 & 0.01 & 1 & Tetulia \\
\hline 16 & Mustard-Mung-T. Aman & 50 & 0.01 & 1 & Atwari \\
\hline 17 & Potato-Mungbean-T. Aman & 50 & 0.01 & 1 & Panchagarh \\
\hline 18 & Coriander-Vegetab-Fallow & 40 & 0.01 & 1 & Debiganj \\
\hline 19 & Mungbean-Aus-T. Aman & 40 & 0.01 & 1 & Birganj \\
\hline 20 & Potato-Chilli-Fallow & 40 & 0.01 & 1 & Tetulia \\
\hline 21 & Lentil-Jute-T. Aman & 35 & 0.01 & 3 & Ranisonkail+Parbatipur+Hakimpur \\
\hline 22 & Blackgram-Jute-T. Aman & 30 & 0.01 & 1 & Boda \\
\hline 23 & Lentil-Vegetab-Vegetab & 30 & 0.01 & 2 & Tetulia+Bochaganj \\
\hline 24 & Mustard-Sesame-T. Aman & 30 & 0.01 & 1 & Boda \\
\hline 25 & S.Potato-Fallow-Fallow & 30 & 0.01 & 1 & Ranisonkail \\
\hline 26 & S.Potato-Jute-T. Aman & 30 & 0.01 & 1 & Boda \\
\hline 27 & Wheat-Chilli-Fallow & 30 & 0.01 & 1 & Thakurgaon \\
\hline 28 & Coriander-Fallow-T. Aman & 20 & 0.00 & 2 & Pirganj+Boda \\
\hline 29 & Coriander-Jute-T. Aman & 20 & 0.00 & 2 & Nawabganj+Parbatipur \\
\hline 30 & Groundnut-F-Blackgram & 20 & 0.00 & 1 & Debiganj \\
\hline 31 & Lentil-Aus-T. Aman & 20 & 0.00 & 1 & Pirganj \\
\hline 32 & Lentil-Fallow-T. Aman & 20 & 0.00 & 2 & Dinajpur+Hakimpur \\
\hline 33 & Lentil-Vegetab-T. Aman & 20 & 0.00 & 1 & Boda \\
\hline 34 & Wheat-Aus-Blackgram & 20 & 0.00 & 1 & Ghoraghat \\
\hline 35 & Chickpea-Aus-T. Aman & 10 & 0.00 & 1 & Pirganj \\
\hline 36 & Lentil-Maize-T. Aman & 10 & 0.00 & 1 & Haripur \\
\hline 37 & Millet(kaon)-F-T. Aman & 10 & 0.00 & 1 & Boda \\
\hline 38 & Potato+Maize-Veg-T. Aman & 10 & 0.00 & 1 & Hakimpur \\
\hline 39 & Vegetab-Aus-Blackgram & 10 & 0.00 & 1 & Hakimpur \\
\hline \multirow[t]{2}{*}{40} & Maize-Sesame-T. Aman & 5 & 0.00 & 1 & Ghoraghat \\
\hline & Total & 2180 & 0.41 & & \\
\hline
\end{tabular}

\section{Third dominant cropping pattern}

Maize-Fallow-T. Aman cropping pattern holds the third largest area coverage 45,980 hectares in Dinajpur region. This area is an equivalent to $8.71 \%$ of NCA in the region. This pattern is distributed over 18 upazilas as same as WheatFallow-T. Aman cropping pattern. Birol upazila has an area of 5,800 ha which stands for $12.61 \%$ of the total area under this pattern in the region
(Table 10). Ranisonkail has the lowest area compared to other upazila and it is just 20 ha.

\section{Fourth dominant cropping pattern}

Fourth dominant cropping pattern PotatoBoro-T. Aman has occupied 26,590 hectares representing 5.04\% share of NCA in Dinajpur region (Table 11). This pattern is distributed over 16 upazilas where Dinajpur sadar ranked 
Table 8. Distribution of the most dominant Boro-Fallow-T. Aman cropping pattern in Dinajpur region, $2014-15$.

\begin{tabular}{|c|c|c|c|c|}
\hline & Upazila & Area (ha) & $\%$ of upazila NCA & $\%$ of the pattern in region \\
\hline 01 & Parbatipur & 20800 & 72.83 & 9.64 \\
\hline 02 & Thakurgaon & 17500 & 32.84 & 8.11 \\
\hline 03 & Chirirbandar & 17100 & 71.97 & 7.92 \\
\hline 04 & Nawabganj & 15900 & 61.23 & 7.37 \\
\hline 05 & Birampur & 14200 & 80.66 & 6.58 \\
\hline 06 & Phulbari & 11500 & 61.33 & 5.33 \\
\hline 07 & Boda & 11000 & 46.92 & 5.10 \\
\hline 08 & Debiganj & 11000 & 45.46 & 5.10 \\
\hline 09 & Dinajpur & 10400 & 37.86 & 4.82 \\
\hline 10 & Pirganj & 9800 & 33.05 & 4.54 \\
\hline 11 & Ghoraghat & 8700 & 72.71 & 4.03 \\
\hline 12 & Birol & 8200 & 27.13 & 3.80 \\
\hline 13 & Birganj & 8000 & 25.76 & 3.71 \\
\hline 14 & Bochaganj & 7800 & 38.75 & 3.61 \\
\hline 15 & Haripur & 6750 & 38.21 & 3.13 \\
\hline 16 & Baliadangi & 6600 & 27.87 & 3.06 \\
\hline 17 & Hakimpur & 6000 & 72.41 & 2.78 \\
\hline 18 & Khansama & 5100 & 33.49 & 2.36 \\
\hline 19 & Panchagarh & 4900 & 19.96 & 2.27 \\
\hline 20 & Kaharol & 4700 & 26.20 & 2.18 \\
\hline 21 & Ranisonkail & 4400 & 18.17 & 2.04 \\
\hline 22 & Tetulia & 3200 & 23.29 & 1.48 \\
\hline \multirow[t]{2}{*}{23} & Atwari & 2300 & 14.11 & 1.07 \\
\hline & Dinajpur region & 215850 & 40.91 & 100.00 \\
\hline
\end{tabular}

Table 9. Distribution of the $2^{\text {nd }}$ dominant Wheat-Fallow-T. Aman cropping pattern in Dinajpur region, $2014-15$.

\begin{tabular}{|c|c|c|c|c|}
\hline & Upazila & Area (ha) & $\%$ of upazila NCA & $\%$ of the pattern in region \\
\hline 01 & Thakurgaon & 7500 & 14.07 & 16.07 \\
\hline 02 & Pirganj & 6600 & 22.26 & 14.14 \\
\hline 03 & Ranisonkail & 5000 & 20.64 & 10.72 \\
\hline 04 & Birganj & 4850 & 15.62 & 10.39 \\
\hline 05 & Baliadangi & 3700 & 15.63 & 7.93 \\
\hline 06 & Kaharol & 3150 & 17.56 & 6.75 \\
\hline 07 & Boda & 3100 & 13.22 & 6.64 \\
\hline 08 & Atwari & 3000 & 18.4 & 6.43 \\
\hline 09 & Tetulia & 3000 & 21.83 & 6.43 \\
\hline 10 & Birol & 1700 & 5.63 & 3.64 \\
\hline 11 & Bochaganj & 1600 & 7.95 & 3.43 \\
\hline 12 & Haripur & 1600 & 9.06 & 3.43 \\
\hline 13 & Chirirbandar & 1000 & 4.21 & 2.14 \\
\hline 14 & Dinajpur sadar & 400 & 1.52 & 0.86 \\
\hline 15 & Debiganj & 200 & 0.85 & 0.43 \\
\hline 16 & Nawabganj & 120 & 0.47 & 0.26 \\
\hline 17 & Parbatipur & 100 & 0.35 & 0.21 \\
\hline \multirow[t]{2}{*}{18} & Hakimpur & 40 & 0.48 & 0.09 \\
\hline & Dinajpur region & 46660 & 8.84 & 100.00 \\
\hline
\end{tabular}


in top position. This upazila has 4,530 ha area which is only $16.49 \%$ of upazila NCA. Birganj upazila ranked in second position with 4,500 ha area for this pattern, while Pirganj holds the lowest position with just 500 hectares area. In the country-wide data compilation it was observed that Potato-Boro-T. Aman was the $8^{\text {th }}$ dominant cropping pattern in Bangladesh covering 1.80 lac ha $(2.11 \%$ of $\mathrm{NCA}$ in the country) with its distribution in 115 upazilas of 33 districts (Nasim et al., 2017).

\section{Fifth dominant cropping pattern}

Fifth dominant cropping pattern PotatoMaize-T. Aman had been covering 26,330 hectares representing $4.99 \%$ share of NCA in Dinajpur region (Table 12). This pattern is distributed over 18 upazilas where Thakurgaon sadar ranked in top position. This upazila had 6,500 ha area for Potato-Maize-T. Aman pattern which is only $12.2 \%$ of upazila NCA and $24.69 \%$ contributor for the region. Birampur and Debiganj occupied the lowest area, which was only 100 ha for each upazila under this cropping pattern.

\section{Crop diversity and cropping intensity}

Higher number of available crops under cultivation in an area dictates its higher diversity. Number of cropping patterns is also a gross indicator of crop diversity. A total of 110 cropping patterns were identified in the whole area of Dinajpur region under this investigation. The highest number of cropping patterns was identified 30 in Boda upazila and that was 26 in Khansama; and 25 in Dinjpur sadar, Debiganj, Tetulia (Table 13). The lowest number of cropping patterns was identified 11 in Kaharol followed by 15 in Birampur. Higher number of cropping patterns is generally related to higher level of diversity indices for cropping pattern. The highest diversity index for cropping pattern was recorded 0.883 in Ranisonkail followed by 0.874 in Panchagarh. The lowest value of diversity index for cropping pattern was found 0.343 in Birampur upazila that was followed by 0.451 in Parbatipur upazila. The highest CDI was reported 0.955 in Ranisonkail followed by 0.952 in Baliadangi. The lowest value of CDI was observed 0.708 in Birampur followed by 0.753 in Ghoraghat upazila. The range of cropping intensity values was recorded $206-249 \%$. The maximum value

Table 10. Distribution of the $3^{\text {rd }}$ dominant Maize-Fallow-T. Aman cropping patterns in Dinajpur region, $2014-15$.

\begin{tabular}{|c|c|c|c|c|}
\hline & Upazila & Area (ha) & $\%$ of upazila NCA & $\%$ of the pattern in region \\
\hline 01 & Birol & 5800 & 19.19 & 12.61 \\
\hline 02 & Nowabganj & 5500 & 21.18 & 11.96 \\
\hline 03 & Panchagarh & 5500 & 22.41 & 11.96 \\
\hline 04 & Kaharol & 5400 & 30.10 & 11.74 \\
\hline 05 & Birganj & 4300 & 13.85 & 9.35 \\
\hline 06 & Dinajpur & 3000 & 10.92 & 6.52 \\
\hline 07 & Atwari & 2500 & 15.33 & 5.44 \\
\hline 08 & Thakurgaon & 2400 & 4.50 & 5.22 \\
\hline 09 & Phulbari & 2200 & 11.73 & 4.78 \\
\hline 10 & Bochaganj & 2000 & 9.93 & 4.35 \\
\hline 11 & Parbatipur & 1900 & 6.65 & 4.13 \\
\hline 12 & Boda & 1550 & 6.61 & 3.37 \\
\hline 13 & Debiganj & 1500 & 6.20 & 3.26 \\
\hline 14 & Khansama & 1300 & 8.54 & 2.83 \\
\hline 15 & Ghoraghat & 800 & 6.72 & 1.73 \\
\hline 16 & Birampur & 200 & 1.14 & 0.43 \\
\hline 17 & Chirirbandar & 110 & 0.47 & 0.24 \\
\hline \multirow[t]{2}{*}{18} & Ranisonkail & 20 & 0.08 & 0.04 \\
\hline & Dinajpur region & 45980 & 8.71 & 100.00 \\
\hline
\end{tabular}


Table 11. Distribution of the $4^{\text {th }}$ dominant Potato-Boro-T. Aman cropping pattern in Dinajpur region, $2014-15$.

\begin{tabular}{llrrr}
\hline & Upazila & Area (ha) & \% of upazila NCA & \% of the pattern in region \\
\hline 01 & Dinajpur & 4530 & 16.49 & 17.04 \\
02 & Birganj & 4500 & 14.49 & 16.92 \\
03 & Parbatipur & 3300 & 11.55 & 12.41 \\
04 & Thakurgaon & 3200 & 6.00 & 12.03 \\
05 & Birol & 1800 & 5.96 & 6.77 \\
06 & Bochaganj & 1300 & 6.46 & 4.89 \\
07 & Birampur & 1200 & 6.82 & 4.51 \\
08 & Phulbari & 1000 & 5.33 & 3.76 \\
09 & Debiganj & 1000 & 4.13 & 3.76 \\
10 & Hakimpur & 800 & 9.65 & 3.01 \\
11 & Ranisonkail & 800 & 3.30 & 3.01 \\
12 & Khansama & 760 & 4.99 & 2.86 \\
13 & Chirirbandar & 700 & 2.95 & 2.63 \\
14 & Ghoraghat & 600 & 5.01 & 2.26 \\
15 & Nawabganj & 600 & 2.34 & 1.26 \\
16 & Pirganj & 500 & 1.72 & 1.88 \\
\hline
\end{tabular}

Table 12. Distribution of the $5^{\text {th }}$ dominant Potato-Maize-T. Aman cropping patterns in Dinajpur region, 2014-15.

\begin{tabular}{llrrr}
\hline & Upazila & Area (ha) & \% of upazila NCA & \% of the pattern in region \\
\hline 01 & Thakurgaon & 6500 & 12.20 & 24.69 \\
02 & Birganj & 3550 & 11.43 & 13.48 \\
03 & Birol & 3000 & 9.93 & 11.39 \\
04 & Haripur & 2500 & 14.15 & 9.49 \\
05 & Khansama & 2300 & 15.10 & 8.74 \\
06 & Kaharol & 2100 & 11.71 & 7.98 \\
07 & Baliadangi & 1550 & 6.55 & 5.89 \\
08 & Pirganj & 1000 & 3.37 & 3.80 \\
09 & Dinajpur & 600 & 2.18 & 2.28 \\
10 & Phulbari & 600 & 3.20 & 2.28 \\
11 & Ghoraghat & 600 & 5.01 & 2.28 \\
12 & Chirirbandar & 500 & 2.14 & 1.90 \\
13 & Parbatipur & 500 & 1.76 & 1.90 \\
14 & Nawabganj & 380 & 1.48 & 1.44 \\
15 & Atwari & 300 & 1.89 & 1.14 \\
16 & Hakimpur & 150 & 1.82 & 0.57 \\
17 & Birampur & 100 & 0.57 & 0.40 \\
18 & Debiganj & 100 & 0.43 & 0.40 \\
\hline & Dinajpur region & 26330 & 4.99 & 100.00 \\
\hline
\end{tabular}

was for Khansama upazila of Dinajpur district and minimum for Boda upazila of Panchagarh district. As a whole, crop diversity index (CDI) for Dinajpur region was calculated 0.924. In a simultaneous study, the investigators identified 316 cropping patterns for whole Bangladesh; where the CDI value was 0.952 at national level and the national average of cropping intensity was 200\% (Nasim et al., 2017). Diversification of crops helps risk reduction as diversification allows a producer to balance low price in one or two crops with reasonable prices in the other. (Blade and Slinkard, 2002). The farmers of Kerala diversified their cropping pattern to minimize risk from due to crop failures and price fluctuations (Mahesh, 1999). 
Table 13. Crop diversity and cropping intensity in Dinajpur region, 2014-15.

\begin{tabular}{|c|c|c|c|c|c|c|}
\hline & Upazila & $\begin{array}{c}\text { No. of identified } \\
\text { pattern }\end{array}$ & No. of crop & $\begin{array}{l}\text { Diversity index for } \\
\text { cropping pattern }\end{array}$ & $\begin{array}{l}\text { Crop diversity } \\
\text { index (CDI) }\end{array}$ & C.I. (\%) \\
\hline 01 & Birampur & 15 & 14 & 0.343 & 0.708 & 214 \\
\hline 02 & Birganj & 19 & 16 & 0.849 & 0.941 & 241 \\
\hline 03 & Birol & 16 & 15 & 0.856 & 0.947 & 246 \\
\hline 04 & Bochaganj & 17 & 14 & 0.811 & 0.927 & 236 \\
\hline 05 & Chirirbandar & 22 & 16 & 0.473 & 0.777 & 219 \\
\hline 06 & Dinajpur & 25 & 16 & 0.809 & 0.925 & 238 \\
\hline 07 & Phulbari & 19 & 15 & 0.600 & 0.837 & 225 \\
\hline 08 & Ghoraghat & 17 & 19 & 0.458 & 0.753 & 212 \\
\hline 09 & Hakimpur & 20 & 19 & 0.456 & 0.774 & 225 \\
\hline 10 & Kaharol & 11 & 13 & 0.794 & 0.909 & 218 \\
\hline 11 & Khansama & 26 & 15 & 0.831 & 0.937 & 249 \\
\hline 12 & Nawabganj & 18 & 18 & 0.578 & 0.803 & 209 \\
\hline 13 & Parbatipur & 16 & 16 & 0.451 & 0.760 & 216 \\
\hline 14 & Atwari & 20 & 19 & 0.852 & 0.935 & 222 \\
\hline 15 & Boda & 30 & 22 & 0.746 & 0.879 & 206 \\
\hline 16 & Debiganj & 25 & 21 & 0.863 & 0.902 & 221 \\
\hline 17 & Panchagarh & 20 & 19 & 0.874 & 0.938 & 203 \\
\hline 18 & Tetulia & 25 & 19 & 0.855 & 0.941 & 240 \\
\hline 19 & Baliadangi & 18 & 14 & 0.859 & 0.952 & 243 \\
\hline 20 & Haripur & 18 & 15 & 0.792 & 0.931 & 247 \\
\hline 21 & Pirganj & 22 & 18 & 0.811 & 0.922 & 228 \\
\hline 22 & Ranisonkail & 24 & 18 & 0.883 & 0.955 & 246 \\
\hline \multirow[t]{2}{*}{23} & Thakurgaon & 19 & 16 & 0.839 & 0.938 & 239 \\
\hline & Dinajpur region & 112 & 25 & 0.807 & 0.924 & 229 \\
\hline
\end{tabular}

\section{CONCLUSION}

The cropping intensity, diversity and land use of the Dinajpur region is little bit higher than the national average but it is not yet enough as we have a vast population and need a huge amount of food everyday. Exclusive rice area is about nine folds of exclusive non-rice area. Abundance of non-rice cereal crops is extraordinary characteristic of the region. Therefore, Dinajpur region can play a vital role through abundant crop production for maintaining the food security of the country. Based on the findings of the study, the following recommendations were made.

- Initiative to be taken to increase productivity of exclusive rice based cropping pattern. As rice is the synonym of the primary food security, the high yielding varieties of rice along with recommended crop management packages to be adopted.
- The upazilas having unique or exceptional cropping patterns with large area coverage might be studied in-depth to extrapolate to similar environments.

- Devotion might be invested so that a portion of double-rice area could be brought under Potato-Boro-T. Aman cropping system or other three cropping systems.

- Scope might be explored for the establishment of agro-based food and feed industry for the best use of potato as well as maize.

\section{REFERENCES}

Agrawal, D J and A H Kassam. 1976. The importance of multiple cropping in increasing world food supplies. A special publication No. 27, American Society of Agronomy, Madison, Wisconsin. pp. 2-3.

Alam, M S. 1994. Optimum cropping patterns of the small farmers under risk: a micro level study in Bangladesh. 
Ph D thesis, Department of Agricultural Economics, Bangladesh Agricultural University, Mymensingh.

BBS (Bangladesh Bureau of Statistics). 2015. Yearbook of Agriculture Statistics of Bangladesh. Bangladesh Bureau of Statistics, Government of the People's Republic of Bangladesh, Dhaka, Bangladesh.

Blade, S F and A E Slinkard. 2002. New Crop Development: The Canadian Experience. In: Trends in New Crops and New Uses. J Janick and A Whipkey (Editors). ASHS Press, Alexandria.

FAO, 1988. Land Resources Appraisal of Bangladesh for Agricultural Development- Report 2: Agroecological regions of Bangladesh. Food and Agriculture Organization of the United Nations, Rome, Italy, 570p.

Gadge, S S. 2003. Influence of changes in cropping pattern on farmers' economic status. Indian J. Ext. Edu. 39(1\&2): 99-101.

Hossain, D. 1996. Relative profitability from alternative cropping patterns under irrigated conditions in selected areas of Bogra district. M. S. Ag. Econ.Thesis. Bangladesh Agricultural University, Mymensingh.

Kshirsagar, K G, S Pandey and M R Bellon. 1997. Farmers' perception, varietal characteristics and technology adoption: the case of rainfed village in eastern India. Discussion paper 5/97. Social Sciences Division, International Rice Research Institute. Los Baňos, Laguna, Philippines.

Mahesh, R. 1999. Causes and consequences of change in cropping pattern: A location-specific study.
Discussion Paper No. 11, Kerala Research Programme on Local Level Development, Centre for Development Studies, Thiruvananthapura.

Mandal, R and M P Bezbaruah. 2013. Diversification of cropping pattern: its determinants and role in flood affected agriculture of Assam Plains. Indian J. Agric. Econ. 68(2): 169-181.

Nasim, M, S M Shahidullah, A Saha, M A Muttaleb, T L Aditya, M A Ali and M S Kabir. 2017. Distribution of Crops and Cropping Patterns in Bangladesh. Bangladesh Rice J. 21(2): 1-55.

Neena, D. 1998. Interstate variation in cropping pattern in India. Indian J. Regi. Sci. 30(2): 57-69.

Rashid M H, A H Khan and M M Alam. 2005. Cropping systems dynamics in greater Khustia. J. Bangladesh Agril. Univ. 3(2):213-238.

Shahidullah, S M, M S A Talukder, M S Kabir, A H Khan and N E Elahi. 2006. Cropping patterns in the South East Coastal Region of Bangladesh. J. Agric. Rural Dev. 4(1\&2): 53-60.

Shirazy, B J, M H Rashid, M M Mahbub, T A Somee and P C Goswami. 2016. Farmers' participatory demonstration of salt tolerant T. Aman rice varieties in saline soils. Academic Journal of Plant Sciences, 9 (1): 01-04.

Shopan, J, M S U Bhuiya, M A Kader and M K Hasan. 2012. The feasibility of crop diversification in rice based cropping systems in haor ecosystem. J. Bangladesh Agril. Univ. 10(2): 211-216.

Shriar, A J. 2000. Agricultural intensity and its measurement in frontier regions. Agroforestry Systems. 49(3): 301-318. 
Appendix 1. List of cropping patterns in Dinajpur region, 2014-15.

\begin{tabular}{|c|c|c|c|c|c|}
\hline & Cropping pattern & Area (ha) & & Cropping pattern & Area (ha) \\
\hline 01 & Boro-Fallow-T. Aman & 215850 & 36 & Garlic-Jute-T. Aman & 980 \\
\hline 02 & Wheat-Fallow-T. Aman & 46660 & 37 & W.Melon-Fallow-T. Aman & 970 \\
\hline 03 & Maize-Fallow-T. Aman & 45980 & 38 & Onion-Vegtab-Vegetab & 850 \\
\hline 04 & Potato-Boro-T. Aman & 26590 & 39 & Onion-Jute-T. Aman & 740 \\
\hline 05 & Potato-Maize-T. Aman & 26330 & 40 & Garlic-Vegetab-Vegetab & 710 \\
\hline 06 & Wheat-Jute-T. Aman & 23960 & 41 & Fallow-Sesame-T. Aman & 700 \\
\hline 07 & Mustard-Boro-T. Aman & 18720 & 42 & Chilli-Jute-T. Aman & 670 \\
\hline 08 & Wheat-Maize-T. Aman & 11520 & 43 & Boro-Fallow-Fallow & 650 \\
\hline 09 & Wheat-Aus-T. Aman & 9990 & 44 & Garlic-Fallow-T. Aman & 570 \\
\hline 10 & Chilli-Fallow-T. Aman & 7560 & 45 & Onion-Fallow-T. Aman & 560 \\
\hline 11 & Wheat-Mungbean-T. Aman & 6280 & 46 & Vegetab-Jute-Fallow & 520 \\
\hline 12 & Vegetab-Vegetab-Vegetab & 5070 & 47 & Potato-Boro-Fallow & 500 \\
\hline 13 & Vegetab-Fallow-T. Aman & 4460 & 48 & Potato-Onion-T. Aman & 500 \\
\hline 14 & Groundnut-Fallow-T. Aman & 3700 & 49 & Vegetab-Fallow-Fallow & 470 \\
\hline 15 & Mustard-Maize-T. Aman & 3590 & 50 & Maize-Jute-T. Aman & 440 \\
\hline 16 & Potato-Jute-T. Aman & 3515 & 51 & Vegetab-Fallow-Blackgram & 405 \\
\hline 17 & Wheat-Fallow-Fallow & 3250 & 52 & Mustard-Jute-T. Aman & 380 \\
\hline 18 & Wheat-Maize-Fallow & 3050 & 53 & Mustard-Fallow-T. Aman & 360 \\
\hline 19 & Wheat-Vegetab-T. Aman & 2920 & 54 & Garlic-Aus-T. Aman & 350 \\
\hline 20 & Potato-Groundnut-T. Aman & 2700 & 55 & Potato-Maize-Vegetab & 350 \\
\hline 21 & Vegetab-Vegetab-T. Aman & 2650 & 56 & Vegetab-Boro-T. Aman & 310 \\
\hline 22 & Potato-Vegetab-T. Aman & 2460 & 57 & Vegetab-Vegetab-Fallow & 310 \\
\hline 23 & Potato-Aus-T. Aman & 2020 & 58 & Fallow-Fallow-T. Aman & 300 \\
\hline 24 & Sesame-Fallow-T. Aman & 2010 & 59 & Groundnut-Jute-T. Aman & 300 \\
\hline 25 & Wheat-Maize-Vegetab & 2000 & 60 & Maize-Aus-Fallow & 300 \\
\hline 26 & Maize-Maize-T. Aman & 1700 & 61 & Maize-Vegetab-T. Aman & 300 \\
\hline 27 & Maize-Vegetab-Fallow & 1700 & 62 & Onion-Aus-T. Aman & 300 \\
\hline 28 & Potato-Maize-Fallow & 1600 & 63 & Vegetab-Groundnut-T. Aman & 300 \\
\hline 29 & Boro-Aus-T. Aman & 1575 & 64 & Maize-Aus-T. Aman & 250 \\
\hline 30 & Mustard-Boro-Fallow & 1490 & 65 & Chilli-Fallow-Fallow & 240 \\
\hline 31 & Potato-Fallow-T. Aman & 1440 & 66 & Vegetab-Aus-T. Aman & 240 \\
\hline 32 & Wheat-Vegetab-Vegetab & 1400 & 67 & Potato-Jute-Fallow & 200 \\
\hline 33 & Groundnut-Fallow-Fallow & 1330 & 68 & Vegetab-Boro-Aus-T. Aman & 200 \\
\hline 34 & Maize-Boro-T. Aman & 1200 & 69 & Chilli-Vegetab-Fallow & 160 \\
\hline \multirow[t]{2}{*}{35} & Vegetab-Maize-T. Aman & 1020 & 70 & Mustard-Aus-T. Aman & 160 \\
\hline & & & $71-110$ & Other 40 patterns (Table 7) & 2180 \\
\hline
\end{tabular}

